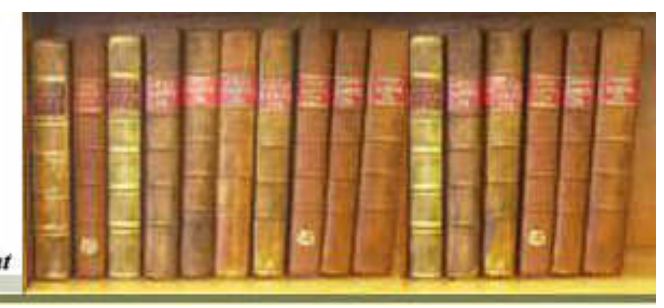

\title{
INTERNATIONAL FINANCIAL REPORTING STANDARD FOR SMALL AND MEDIUM- SIZED ENTITIES
}

\author{
ZR Koppeschaar \\ Department of Financial Accounting \\ School of Accounting Sciences \\ University of South Africa (UNISA) \\ Postal address: PO Box 66531, Woodhill, 0076, South Africa \\ Tel: + 27(012) 429-4717; 0832715576 \\ E-mail: koppezr@unisa.ac.za
}

\begin{abstract}
The International Financial Reporting Standard for Small and Medium-sized entities (IFRS for SMEs) was published as a standard by the International Accounting Standards Board (IASB) during July 2009. During 2007 South Africa became one of the first countries and the first country in Africa to early accept the proposed accounting standard (exposure draft of an IFRS for SMEs). The accounting standard will probably also be accepted by numerous other countries. The aim of this article is to investigate the applicability of this accounting standard. The results indicated that the IFRS for SMEs remains too comprehensive for the majority of small companies. The IFRS for SMEs does not satisfy the needs of South African users of small company financial statements, and as a result the accounting requirements should be simplified.
\end{abstract}

\section{KEYWORDS}

Financial accounting; Financial reporting requirements; IFRS for SMEs; Small companies; Users of financial statements; Small company financial statements. 


\section{INTRODUCTION AND MOTIVATION}

The International Financial Reporting Standard for Small and Medium-sized entities (IFRS for SMEs) was published as a standard by the International Accounting Standards Board (IASB) during July 2009 (IASB, 2009a; IASB, 2009b). With regard to the IFRS for SMEs, Sir David Tweedie, chairperson of the IASB, released the following statement to the press on 9 July 2009: "The publication of IFRS for SMEs is a major breakthrough for companies throughout the world. For the first time, SMEs will have a common high quality and internationally respected set of accounting requirements." (IASB, 2009c). During 2007 South Africa became one of the first countries and the first country in Africa to early accept the proposed accounting standard (exposure draft of an IFRS for SMEs) (SAICA, 2007a). Since then the IFRS for SMEs has also been adopted in Australia as part of their differential reporting system. The accounting standard will probably also be accepted by numerous other countries (Sealy-Fisher, 2009:32).

The aim of this article is to investigate the opinions of South African small company practitioners, as compilers of small company financial statements, on the applicability of this accounting standard (IFRS for SMEs). Small businesses usually provide a substantial contribution to a country's economy by, among others, creating new job opportunities, serving as a platform for the foundation of new businesses, and by creating an important link in the supply chain (Nieman, 2006:9). The importance of small businesses in an economy should not be underestimated. Nieman (2006:12) confirms that small businesses also play a very important part in the South African economy. As a result, the financial statements of these businesses are also important.

The current IFRS reporting framework creates problems for small companies because of the comprehensiveness of the current reporting requirements and the high cost of compliance (Cleminson \& Rabin, 2002:346; Kruger 2004:196; Stainbank \& Wells, 2007:49; Van Wyk \& Rossouw, 2008:22). Small companies have few staff members, with often limited financial expertise, and limited resources. They have to incur substantial additional costs to adhere to the IFRS requirements that require increasingly complex technical calculations, extensive disclosure and high level of accounting expertise. According to Plewa and Friedlob (1989:55) these costs bring about a unique financial burden for small companies. Research in the USA (Patel, 1991:80) indicates that, in relation to larger companies, small companies incur relatively greater costs in order to adhere to reporting requirements. The increasing complexity of the business environment probably results in stricter reporting requirements as well as increased costs. As a result of increased costs that small companies incur in order to prepare financial statements, such costs may exceed the advantages gained by supplying the correct information (Boymal, 2006:107).

Numerous practitioners, owners, professional accounting organisations and several researchers support the adoption of a system of differential reporting for SMEs (Patel, 1991:80; Barcelo, 2007:25; Shearer \& Sleigh-Johnson, 2007:78). The United Kingdom, Australia, New Zealand and Canada have already implemented a form of differential reporting for small companies. The solutions implemented by these countries differ substantially; which may be an indication of both the importance and the complexity of differential reporting.

This study will benefit countries considering the adoption of the IFRS for SMEs, practitioners and small companies by indicating that the IFRS for SMEs remains too comprehensive and that further simplified reporting requirements for small companies are justified. At a theoretical level, the findings are significant because they expand the literature by focusing on differential reporting and specifically the application of the IFRS for SMEs, a relatively 
unexplored area in Africa. Small and Medium-sized entities include different forms of businesses, for example private companies, close corporations, trusts, partnerships, etc. The IFRS for SMEs is only applicable to private companies in South Africa and as a result the empirical study only includes these companies. The limitation of the study is that the results only apply to small companies (private companies) in South Africa.

The subject field covered in this article is set out in the following sections: section 2 outlines the background to the study and the literature review, including a historical overview of the development of differential reporting in various countries, section 3 discusses the empirical tests used in this study to determine to what extent small companies are abreast of the accounting standards (IFRSs) and the IFRS for SMEs and to identify the specific accounting standards (IFRSs) applicable to small companies, section 4 reports the results of the research and section 5 contains the conclusions and recommendations.

\section{THEORETICAL BACKGROUND}

\section{Harmonising}

Financial reporting has adapted to the requirements of a fast changing environment in order to ensure that accounting information communicated to users through financial statements provide a fair account of transactions, circumstances and events. The complexity and scope of accounting requirements have increased considerably and this has had an impact on the costs involved in the preparation of financial statements (Chigbo, 1998:30). Walton (1998:2) argues that accountants and those who prepare accounting standards acknowledge the fact that there is a need in worldwide capital markets for companies to provide comparable financial statements; thus a move towards harmonisation.

The advantages of the harmonisation of accounting standards are not limited to entities trading securities on capital markets, but also to small and medium-sized entities, due to the following reasons, (IASB, 2007b:BC16):

- Financial institutions allocate loans internationally and are operated multi-nationally. Banks use financial statements when decisions on loans are taken and credit terms and interest rates are fixed;

- Sellers need to evaluate the financial abilities of buyers' in other countries prior to supplying goods and services on credit;

- Credit agencies try to develop uniform international valuations;

- Capital enterprises funds small entities internationally; and

- Many small entities have foreign investors not directly involved in the management of the relevant entity.

Although the harmonisation of accounting standards holds advantages for smaller companies, it results in comprehensive and complex accounting reporting requirements and probably contribute to the problem of an overload of accounting standards for small companies. By issuing the international accounting standard for small and medium-sized entities, the IASB moved towards the harmonisation of accounting standards also for small entities (IASB, 2007a:BC15).

\section{Development of differential reporting in South Africa}

The first suggestion for differential reporting in South Africa, Discussion Paper (DP) 16, Limited purpose financial statements, was issued by the South African Institute of Chartered Accountants (SAICA) in May 2000 (SAICA, 2000). The aim of the paper was to determine whether respondents supported differential reporting. The suggestions included in the 
discussion document were received positively and a move towards differential reporting was welcomed by all respondents (Hattingh, 2002:23; Heymans, 2000:31).

In June 2003, an exposure draft that simplified the exposure requirements for small companies, ED 163, Framework for the preparation and presentation of limited purpose financial statements, was issued by SAICA (SAICA, 2003). Notwithstanding the fact that the exposure draft would have reduced the reporting burden on small companies in South Africa, the exposure draft was never issued as an accounting standard and consequently never applied in practice. During May 2007, ED 225, Financial reporting for small and medium-sized entities - Proposed process, was also issued by SAICA (SAICA, 2007b). This exposure draft is exactly the same as the proposed IFRS for SMEs issued by the IASB. It resulted in the early adoption of the IFRS for SMEs.

\section{Historical overview}

Internationally differential reporting has been implemented in various forms by different countries. The following countries played an important role in the application of differential reporting: Australia, New Zealand, United Kingdom and Canada. The international implementation of differential reporting will now be discussed by referring to a short historical overview of the development of differential reporting in the abovementioned countries.

\section{Australia}

Since the issuing of the Statement of Accounting Concepts 1 (SAC 1): Definition of the Reporting Entity; Accounting Standard AASB 1025: Application of the Reporting Entity Concept and Other Amendments; as well as the modification of the Corporations Law of 1989, differential reporting was implemented in Australia during 1992. The differential reporting approach accepted in Australia in SAC 1 and AASB 1025 is based on a dual reporting/non-reporting entity principle (ICAA, 2204; ICAA, 2006; Kent \& Munro, 1999:360). Entities classified as reporting entities must adhere to all accounting standards. Entities classified as non-reporting entities may deviate from the accounting standards and provide a lower level of disclosure in their financial statements when compared to those of reporting entities (Kent \& Munro, 1999:360). However, Boymal (2006:110) concludes that the reporting-entity principle is probably outdated and that a revised differential reporting system, with reference to cost-benefit analyses, should be applied.

During 2009 the AASB concluded that the Australian accounting reporting system should effect a shift in emphasis and that the focus should no longer be on the reporting-entity principle, but on general-purpose financial statements (AASB, 2009). As a result the IFRS for SMEs issued by the IASB, was issued by the AASB as the IFRS for Non-Publicly Accountable Entities (NPAEs) and was accepted in Australia during 2009. A dual-level differential reporting system was approved by the AASB for profitable entities (AASB, 2009):

- Level 1 applies to general-purpose financial statements of public reporting entities and involves the application of the complete IFRSs.

- $\quad$ Level 2 applies tot general-purpose financial statements of non-public reporting entities and involves a choice: applying the IFRS for NPAEs (as accepted in Australia) or an alternative system which involves the application of the complete recognition and measurement requirements of the complete IFRSs, as well as limited disclosure.

Non-public companies may also choose to adhere to the complete IFRSs.

However, the Australian reporting system does provide for a third level of reporting for entities that are non-reporting entities according to the Australian Corporations Act (small companies limited by guarantee). Entities qualify as non-reporting entities when they adhere to certain criteria with regard to size. The financial statements of these entities, i.e. specialpurpose financial statements, should only adhere to the following three accounting standards 
(AASB, 2009): AASB 101: Presentation of Financial Statements; AASB 107: Cash Flow Statements; en AASB 108: Accounting Policies, Changes in Accounting Estimates and Errors. From the above-mentioned discussion it seems as though a comprehensive differential reporting system has been successfully implemented in Australia.

\section{New Zealand}

Differential reporting has been applied in New Zealand since 1994 (Santoro, 1997:23). The Framework for Differential Reporting was issued by the Institute of Chartered Accountants in New Zealand (ICANZ) during February 1994. Since the initial issuing of the framework it has been revised a number of times - the last revision wat in January 2007 (ICANZ, 2007:par.1). The reporting system in New Zealand allows for four different reporting options (ICANZ, 2007:par.4). The first reporting option applies to entities that are exempt in terms of the requirements of the Financial Reporting Act 1993. A company qualifies as an exempt company only if it adheres to certain criteria regarding size (turnover, assets and number of workers). This option is available to small companies (micro entities) with minimal reporting requirements. The second reporting option applies to companies that produce generalpurpose financial statements and qualify for differential reporting. Companies qualify for differential reporting only if the company does not have public accountability, ownership and management of the company are not separated and the company adheres to certain criteria regarding size (with reference to turnover, assets and number of workers). The Framework for Differential Reporting applies to these companies. The third reporting option applies to companies that produce general-purpose financial statements, has public accountability and do not qualify for differential reporting. These companies must adhere to the requirements of all applicable accounting standards. The fourth reporting option applies to entities that do not publish general-purpose financial statements. These entities produce special-purpose financial statements based on their specific reporting needs.

The differential reporting requirements included in the Framework for Differential Reporting provides for the exclusion of certain accounting standards, the partial exclusion of certain accounting standards as well as non-exclusion of accounting standards. Baskerville and Simpkins (1997:14) maintain that this framework is probably the most comprehensive method of differential reporting. This framework has been applied in New Zealand for almost 15 years and has been reviewed and updated a number of times. Resulting from the recent issuing of the international standard, IFRS for SMEs, Sealy-Fisher (2009:32) maintains that the Institute of Chartered Accountants in New Zealand will probably investigate the acceptance as well as the use and application of this standard in New Zealand.

\section{United Kingdom}

Since 1994 the application of accounting standards for small companies has caused problems for those who prepare accounting standards in the United Kingdom (ASB, 2008:Appendix IV). The Financial Reporting Standard for Smaller Entities (FRSSE) was issued in November 1997. The FRSSE was designed to provide a single accounting standard for smaller entities and focuses on their specific circumstances (ASB, 2008:Appendix IV). Smaller entities that chose to apply the FRSSE were exempted from all other accounting standards. When the FRSSE was issued it was clear that the document needed to be reviewed on a regular basis in order to take developments in accounting into account; as a result the FRSSE was reviewed a number of times since it was issued in 1997. The differential requirements included in the FRSSE are a combination of the exclusion of certain accounting standards; the reduction of some disclosure requirements; and the simplification of certain recognition and measurement criteria.

For more than a decade small entities have used the FRSSE in the United Kingdom and according to King (1997:69), the FRSSE have been designed to satisfy almost all the needs of users of small entities' statements; furthermore, the FRSSE also provides a single point of 
reference for reporting for the majority of small entities. However, since being issued in 1997, the FRSSE has been continuously criticised for various reasons (Murphy \& Page, 1998:64; Perrin, 1997:1). A study by the Irish Accountancy Educational Trust concluded that the FRSSE was unable to lessen the reporting burden of small entities and small practitioners (McAleese, 2001:18). However, the application of the FRSSE in the United Kingdom is a clear indication of the successful implementation of differential reporting. According to Shearer and Sleigh-Johnson (2006:79), as a result of the issuing of the IFRS for SMEs, the United Kingdom will in future probably move towards three levels of reporting while the FRSSE will be retained.

\section{Canada}

In 1980 differential reporting was considered in Canada for the first time. Research by Ashby (1980:29) identified the costs of preparing financial statements and the complexity of accounting standards as one of the most important problems experienced by small businesses. The issue of differential reporting was also investigated by the Canadian Institute of Chartered Accountants (CICA) and, as a result, the concept, Exposure draft: Differential Reporting, was issued during 2001(CICA, 2001), and eventually the accounting standard, Differential Reporting, Section 1300 and related amendments to other Sections (CICA, 2002) was issued during February 2002. According to these, differential reporting options were available for qualifying entities. Such entities were entities without public accountability and entities of which the owners unanimously agreed (in writing) that differential reporting may be applied. Differential reporting options simplify disclosure requirements as well as recognition and measurement requirements for qualifying entities regarding the following issues: subsidiaries, long-term investments, share capital, income tax, and financial instruments.

During $2006 \mathrm{CICA}$ decided to further investigate the needs of users of private entity financial statements in order to determine which financial reporting approach would best satisfy the needs of these users (CICA, 2007:par.6; Maingot \& Zeghal, 2006:513). As a result, the disclosed concept, Exposure draft: Generally Accepted Accounting Principles for Private Enterprises, was issued during May 2009. The disclosed concept is only applicable to private entities (entities without public accountability), while non-profit organisations are specifically excluded. To qualify as private entity no other requirements regarding the number of or permission by members exist. The disclosed concept includes various modifications and simplifications of recognition and measurement requirements with regard to various subjects (CICA 2009).

The Canadian differential reporting options are flexible and qualifying entities may choose options based on their specific needs and cost-benefit limitations. According to Jeffrey (2007:26), it has been suggested that the differential reporting system within IFRSs should be divided into three reporting levels: level 1 for large companies, level 2 for medium companies and level 3 for small entities. The Canadian differential reporting model provides for the reduction of disclosure requirements as well as the simplification of recognition and measurement criteria. The initial model has been successfully implemented in practice. This not only confirms the need for a differential reporting system, but also indicates the applicability thereof. There are however no indications that the IFRS for SMEs will be adopted in Canada in the near future.

\section{EMPIRICAL TESTS}

The primary objective of the study was to investigate the opinions of South African small company practitioners, as compilers of small company financial statements, on the applicability of the IFRS for SMEs. The study used a survey of the opinions of practitioners 
responsible for the drafting of financial statements of small companies in South Africa. The following secondary objectives support the primary objective of the study:

- $\quad$ Determining whether it places a burden on small companies to adhere to accounting standards.

- $\quad$ Determining to what extent small companies are abreast of the accounting standards (IFRSs) and the IFRS for SMEs.

- $\quad$ Identifying the specific accounting standards (IFRSs) applicable to small companies.

- Identifying potential issues regarding relaxation of accounting standards.

Although the owners or management of a small company are responsible for the preparation of the company's financial statements, most small companies use their accountants/practitioners to fulfil these accounting functions. Small company practitioners are important in this empirical investigation, as they are responsible for preparing the financial statements of small companies as well as the application of the applicable accounting standards in South Africa. The owners or managements of small companies often lack accounting knowledge and are not the best sources to use in order to gain information about the application of accounting standards. (Van Wyk \& Rossouw, 2008:18).

A large number practitioners are registered with the South African Institute of Chartered Accountants (SAICA), that is also responsible for the development of accounting standards in South Africa. Although the SAICA is not the only accounting professional body in South Africa, it is the professional body with the most members in South Africa. SAICA's database of small practitioners was used as the population. The applicable questionnaire was sent electronically to the entire population with the support of SAICA.

The practitioners were asked to complete and return the questionnaire to SAICA. A follow-up e-mail was sent a month after the distribution of the questionnaires. A second follow-up, requested practitioners who had not completed the questionnaire in the first two rounds to complete the questionnaire a few weeks later. A letter, in which the importance of the study, as well as the importance of the practitioners' input on the differential accounting reporting in South Africa, were emphasised, accompanied this e-mail. The completed questionnaires returned to SAICA were processed by SAICA's computer section.

The questionnaires were send to 1700 small practitioners and 434 completed questionnaires were received back (a response rate of $26 \%$ ). The high response rate can be attributed to SAICA's support for this research study, as well as their willingness to provide their database of small practitioners and the services of their computer department.

\section{RESULTS}

\section{General aspects}

Only $21 \%$ of small practitioners are of the opinion that small company financial statements comply with all the applicable accounting standards (IFRSs). The majority of small practitioners $(79 \%)$ indicated that small company financial statements do not comply fully with the applicable accounting requirements. This confirms that in practice the reporting requirements are inappropriate for small companies and that accounting requirements do not satisfy the needs of the users. It furthermore indicates that the information that should currently be included in small company financial statements are not useful for users and thus do not satisfy users' needs for information. From additional comments received, it is clear that small practitioners are not satisfied with the reporting requirements. Among others, the following statements were made: 
- $\quad$ "Clients try to comply but in most cases it is impossible due to financial and expertise constraints and in most cases compliance serves no purpose whatsoever.

- I challenge anyone who says they fully comply; it is almost impossible (and largely irrelevant to clients).

- It will be very difficult and it will serve no real purpose for them to comply with IFRSs.

- There is no economic benefit or justification to comply."

In practice the majority of small company financial statements do not fully comply with the applicable accounting requirements. The requirements should therefore be simplified in South Africa in order to ensure that the requirements are appropriate for small companies. It is important to note that if small company financial statements do not comply with applicable accounting standards (IFRSs), it will, in future, have significant implications for the owners/managements and those who prepare financial statements in South Africa, as the new Companies Act (2008) provides legal support for the accounting standards (South Africa, 2008). The new Companies Act (2008) is not yet implemented. As a result noncompliance to the applicable accounting standards will be a contravention of the Companies Act in future.

When asked whether it places a burden on small companies to adhere to accounting standards applicable to small companies, $93 \%$ of small practitioners indicated that this was the case. Only $6 \%$ of practitioners were of the opinion that this did not place a burden on small companies. Accounting has, in order to ensure fair accounts of financial transactions, adapted to the requirements of a changing environment. This resulted in comprehensive accounting standards. Over the years this situation developed even further until it reached the stage where it has become a serious problem for small companies. This problem is often referred to as the accounting standards overload problem (Burke, 1997:11; Barcelo, 2007:25). It seems as though the overload of accounting standards remains a real problem for small companies in South Africa. This issue resulted in varied comments by the small practitioners. Their dissatisfaction with the application of the accounting standards is clear from the following examples of comments:

- "The burden on SMEs is beyond comprehension.

- The standards are making financial statements more difficult for the man on the street to understand.

- There is no benefit for the client."

Respondents were asked to indicate to what extent they (small practitioners) are abreast of the accounting standards (IFRSs) and the IFRS for SMEs. From the questionnaire is seems as though the majority of small practitioners (60\%) are of the opinion that they are abreast of the applicable accounting requirements as well as the the IFRS for SMEs (69\%). This is probably the case as the small practitioners are qualified accountants and possess the necessary academic qualifications. All the small practitioners are also registered members of SAICA and they are continuously encouraged to stay abreast of new developments and have to comply with SAICA's CPD (Continuing Professional Development) requirements. One can thus deduce that, at present, small company financial statements do not adhere to the applicable accounting requirements in South Africa - not because the compilers do not posses the necessary knowledge, but rather because the information required does not satisfy the needs of those who use the financial statements and is too expensive to produce. 


\section{Applicability of accounting standards}

The questionnaire included a question on the application of specific accounting standards (IFRSs) in order to determine which standards are actually applied in practice. All IASB accounting standards are included in the questionnaire in order to determine the relevance of individual standards to the accounting reporting of small companies in South Africa. The results are reflected in table 1.

Table 1: Application of accounting standards (IFRSs - International Financial Reporting Standards)

\begin{tabular}{|c|c|c|c|c|c|c|c|}
\hline Order & & Accounting standard & Average & 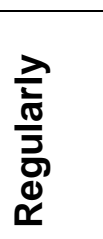 & 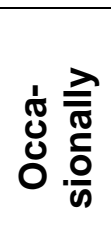 & 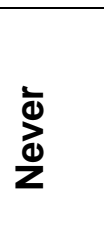 & 吾 \\
\hline 1 & IAS 12 & Income Taxes & 2.74654 & $79 \%$ & $16 \%$ & $5 \%$ & $100 \%$ \\
\hline 2 & IAS 1 & Presentation of Financial Statements & 2.72581 & $78 \%$ & $17 \%$ & $5 \%$ & $100 \%$ \\
\hline 3 & IAS 16 & Property, Plant and Equipment & 2.71889 & $77 \%$ & $18 \%$ & $5 \%$ & $100 \%$ \\
\hline 4 & IAS 18 & Revenue & 2.68664 & $75 \%$ & $18 \%$ & $7 \%$ & $100 \%$ \\
\hline 5 & IAS 7 & Cash Flow State & 2.59447 & $71 \%$ & $18 \%$ & $11 \%$ & $100 \%$ \\
\hline 6 & IAS 2 & Inventories & 2.50230 & $58 \%$ & $34 \%$ & $8 \%$ & $100 \%$ \\
\hline 7 & IAS 40 & Investment Pro| & 2.35714 & $48 \%$ & $40 \%$ & $12 \%$ & $100 \%$ \\
\hline 8 & IAS 17 & Leases & 2.33180 & $48 \%$ & $38 \%$ & $14 \%$ & $100 \%$ \\
\hline 9 & IAS 37 & $\begin{array}{l}\text { Provisions, Contingent Liabilities and } \\
\text { Contingent Assets }\end{array}$ & 2.22811 & $37 \%$ & $49 \%$ & $14 \%$ & $100 \%$ \\
\hline 10 & IAS 24 & Related Party Disclosure & 2.20046 & $43 \%$ & $34 \%$ & $23 \%$ & $100 \%$ \\
\hline 11 & IAS 8 & $\begin{array}{l}\text { Accounting Policies, Changes in } \\
\text { Accounting Estimates and Errors }\end{array}$ & 2.09677 & $33 \%$ & $43 \%$ & $24 \%$ & $100 \%$ \\
\hline 12 & IAS 10 & Events after the Balance Sheet Date & 2.07604 & $31 \%$ & $46 \%$ & $23 \%$ & $100 \%$ \\
\hline 13 & IAS 23 & Borrowing Costs & 2.03226 & $32 \%$ & $39 \%$ & $29 \%$ & $100 \%$ \\
\hline 14 & IAS 36 & Impairment of Assets & 1.97696 & $24 \%$ & $50 \%$ & $26 \%$ & $100 \%$ \\
\hline 15 & IAS 39 & $\begin{array}{l}\text { Financial Instruments: Recognition and } \\
\text { Measurement }\end{array}$ & 1.94700 & $25 \%$ & $44 \%$ & $31 \%$ & $100 \%$ \\
\hline 16 & IAS 32 & Financial Instruments: Presentation & 1.92627 & $28 \%$ & $37 \%$ & $35 \%$ & $100 \%$ \\
\hline 17 & IAS 38 & Intangible Assets & 1.91935 & $15 \%$ & $62 \%$ & $23 \%$ & $100 \%$ \\
\hline 18 & IFRS 7 & Financial Instruments: Disclosure & 1.86175 & $22 \%$ & $42 \%$ & $36 \%$ & $100 \%$ \\
\hline 19 & IAS 21 & $\begin{array}{l}\text { The Effects of Changes in Foreign } \\
\text { Exchange Rates }\end{array}$ & 1.73041 & $15 \%$ & $43 \%$ & $42 \%$ & $100 \%$ \\
\hline 20 & IAS 19 & Employee Benefits & 1.68894 & $17 \%$ & $34 \%$ & $49 \%$ & $100 \%$ \\
\hline 21 & IAS 11 & Construction Contracts & 1.64286 & $11 \%$ & $43 \%$ & $46 \%$ & $100 \%$ \\
\hline 22 & IFRS 1 & First-time Adoption of IFRS & 1.57834 & $11 \%$ & $35 \%$ & $54 \%$ & $100 \%$ \\
\hline 23 & IAS 28 & Investments in Associates & 1.56912 & $7 \%$ & $43 \%$ & $50 \%$ & $100 \%$ \\
\hline 24 & IAS 27 & $\begin{array}{l}\text { Consolidated and Separate Financial } \\
\text { Statements }\end{array}$ & 1.56452 & $8 \%$ & $40 \%$ & $52 \%$ & $100 \%$ \\
\hline 25 & IAS 41 & Agriculture & 1.55300 & $7 \%$ & $40 \%$ & $53 \%$ & $100 \%$ \\
\hline 26 & IAS 20 & $\begin{array}{l}\text { Accounting for Government Grants and } \\
\text { Disclosure of Government Assistance }\end{array}$ & 1.42166 & $6 \%$ & $31 \%$ & $63 \%$ & $100 \%$ \\
\hline
\end{tabular}




\begin{tabular}{|c|c|c|c|c|c|c|c|}
\hline Order & & Accounting standard & Average & 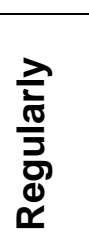 & 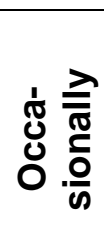 & 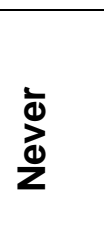 & $\stackrel{\frac{\pi}{0}}{\stackrel{0}{0}}$ \\
\hline 27 & IAS 31 & Interests in Joint Ventures & 1.41705 & $4 \%$ & $33 \%$ & $63 \%$ & $100 \%$ \\
\hline 28 & IFRS 5 & $\begin{array}{l}\text { Non-current Assets Held for Sale and } \\
\text { Discontinued Operations }\end{array}$ & 1.30645 & $5 \%$ & $21 \%$ & $74 \%$ & $100 \%$ \\
\hline 29 & IFRS 3 & Business Combinations & 1.26959 & $1 \%$ & $24 \%$ & $74 \%$ & $100 \%$ \\
\hline 30 & IAS 26 & $\begin{array}{l}\text { Accounting and Reporting by } \\
\text { Retirement Benefit Plans }\end{array}$ & 1.19585 & $2 \%$ & $16 \%$ & $82 \%$ & $100 \%$ \\
\hline 31 & IAS 33 & Earnings per Share & 1.18894 & $4 \%$ & $10 \%$ & $86 \%$ & $100 \%$ \\
\hline 32 & IAS 34 & Interim Financial Reporting & 1.15668 & $2 \%$ & $12 \%$ & $86 \%$ & $100 \%$ \\
\hline 33 & IFRS 2 & Share-based Payment & 1.08756 & $0 \%$ & $8 \%$ & $92 \%$ & $100 \%$ \\
\hline 34 & IFRS 8 & Operating Segments & 1.08756 & $1 \%$ & $7 \%$ & $92 \%$ & $100 \%$ \\
\hline 35 & IFRS 6 & $\begin{array}{l}\text { Exploration and Evaluation of Mineral } \\
\text { Resources }\end{array}$ & 1.08065 & $0 \%$ & $7 \%$ & $93 \%$ & $100 \%$ \\
\hline 36 & IFRS 4 & Insurance Contracts & 1.07834 & $0 \%$ & $8 \%$ & $92 \%$ & $100 \%$ \\
\hline 37 & IAS 29 & $\begin{array}{l}\text { Financial Reporting in Hyperinflationary } \\
\text { Economies }\end{array}$ & 1.03456 & $0 \%$ & $3 \%$ & $97 \%$ & $100 \%$ \\
\hline
\end{tabular}

From the above-mentioned table it appears that in preparing financial statements for small companies, only six of the accounting standards are regularly applied in practice by the majority of small practitioners (more than $50 \%$ ). These standards are the following:

- IAS 12: Income Taxes

- IAS 1: Presentation of Financial Statements

- IAS 16: Property, Plant and Equipment

- IAS 18: Revenue

- IAS 7: Cash Flow Statements

- IAS 2: Inventories

Two accounting standards are in practice regularly applied by $48 \%$ of small practitioners, namely:

- IAS 40: Investment Property

- IAS 17: Leases

In practice, the majority of small practitioners (more than 50\%) never apply several of the accounting standards (see table 1, orders 22 to 37). The accounting standards that are applied regularly relate to the presentation of financial statements (IAS 1: Presentation and Exposure of Financial Statements; IAS 7: Cash Flow Statements), assets and liabilities (IAS 16: Property, Plant and Equipment; IAS 2: Inventories) and income and expenditure (IAS 12: Income Tax; IAS 18: Revenue).

From discussions with small practitioners during the administering of the questionnaire it seemed that small practitioners applied the accounting standard, IAS 12: Income Taxes, in its entirety and that small companies did not find the provision of deferred tax problematic at all. The IFRS for SMEs also requires that provisions should be made for deferred tax. 
The IFRS for SMEs includes reduced disclosure requirements as well as simplified measurement requirements with regard to the six accountings standards regularly applied by the majority of small practitioners. According to the IFRS for SMEs, property, plant and equipment (IAS 16: Property, Plant and Equipment) is accounted for by applying the cost model (the revaluation method is not applicable); the annual revision of the residual values, useful lifespan and depreciation methods are not required. From the questionnaire it also became clear that cash flow statements do provide useful information for users of small company financial statements.

\section{Relaxation of accounting standards for SMEs}

The respondents were asked to identify factors that could reduce the burden of producing financial statements for SMEs. The results are indicated in table 2.

Table 2: Lessening the burden of preparing financial statements

\begin{tabular}{|c|c|c|c|c|c|c|}
\hline & \multicolumn{2}{|c|}{ Yes } & \multicolumn{2}{|c|}{ No } & \multicolumn{2}{|c|}{ Total } \\
\hline $\begin{array}{l}\text { Complete exemption of adherence to a specific } \\
\text { accounting framework }\end{array}$ & 261 & $60 \%$ & 173 & $40 \%$ & 434 & $100 \%$ \\
\hline Reduce disclosure requirements & 417 & $96 \%$ & 17 & $4 \%$ & 434 & $100 \%$ \\
\hline $\begin{array}{l}\text { Decrease the number of applicable accounting } \\
\text { standards }\end{array}$ & 418 & $96 \%$ & 16 & $4 \%$ & 434 & $100 \%$ \\
\hline $\begin{array}{l}\text { Remove audit requirements for private } \\
\text { companies }\end{array}$ & 306 & $71 \%$ & 128 & $29 \%$ & 434 & $100 \%$ \\
\hline Simplify measurement requirements & 422 & $97 \%$ & 12 & $3 \%$ & 434 & $100 \%$ \\
\hline Special standard for small companies & 382 & $88 \%$ & 52 & $12 \%$ & 434 & $100 \%$ \\
\hline
\end{tabular}

The majority of small practitioners indicated that all the items listed would reduce the burden on small companies in preparing financial statements. It is clear that a need exists for the adaptation of the accounting reporting system by simplifying the measurement requirements $(97 \%)$ and a relaxation in the disclosure requirements $(96 \%)$. According to $96 \%$ of respondents the number of accounting standards should be decreased. Small practitioners $(88 \%)$ are also of the opinion that special standards for small companies would lessen the burden of preparing financial statements on these entities. The need for the simplification of the accounting standards applicable to small companies is also evident from the additional comments of small practitioners on the above-mentioned question. Some of the comments are:

- "Special standard for SME - this standard (IFRS for SMEs) is not simple enough and therefore does not reduce the accounting burden.

- Standards for SMEs need to be simplified, but need to be relevant.

- Special standards must be meaningful - not like IFRS for SMEs, which is no help at all.

- Concentrate on risk and users."

According to $71 \%$ of respondents the audit requirements for private companies should be abolished. In terms of new legislation in South Africa these audit requirements for private companies have been abolished.

The following question to respondents specifically addressed the IFRS for SMEs. The majority of small practitioners (60\%) are of the opinion that the IFRS for SMEs do not lessen the burden of the preparing financial statements for small companies significantly. This is also clear from additional comments by small practitioners on the previous questions. The IFRS for SMEs (current applicable accounting reporting requirements) are still too 
comprehensive and accounting standards for small companies should thus be simplified even further.

Respondents were asked to comment on the need for an additional framework. Of the small practitioners, $88 \%$ are of the opinion that the accounting standards currently applicable to small companies are inadequate and that there is a need for a further simplified accounting reporting framework. Only $8 \%$ of respondents indicated that there is no need for an additional reporting framework. This confirms that users of small company financial statements do not use or need the comprehensive information supplied in general financial statements, and that they do not have the same financial reporting needs as users of large company financial statements.

The potential issues regarding the relaxation of the accounting standards are indicated in the table below.

Table 3: Potential issues regarding relaxation of accounting standards

\begin{tabular}{|c|l|c|c|c|c|c|c|c|c|}
\hline Order & \multicolumn{2}{|c|}{ Potential issues } & \multicolumn{2}{c|}{ Concerned } & \multicolumn{2}{c|}{$\begin{array}{l}\text { Un- } \\
\text { concerned }\end{array}$} & \multicolumn{2}{c|}{ No opinion } & \multicolumn{3}{c|}{ Total } \\
\hline 1 & $\begin{array}{l}\text { Non-acceptance of financial } \\
\text { statement by financial } \\
\text { institutions }\end{array}$ & 264 & $61 \%$ & 158 & $36 \%$ & 12 & $3 \%$ & 434 & $100 \%$ \\
\hline 2 & $\begin{array}{l}\text { Non-acceptance of financial } \\
\text { statements by South African } \\
\text { Revenue Services (SARS) }\end{array}$ & 246 & $57 \%$ & 170 & $39 \%$ & 18 & $4 \%$ & 434 & $100 \%$ \\
\hline 3 & $\begin{array}{l}\text { Reduction in financial } \\
\text { statements' reliability }\end{array}$ & 226 & $52 \%$ & 189 & $44 \%$ & 19 & $4 \%$ & 434 & $100 \%$ \\
\hline 4 & $\begin{array}{l}\text { Loss of credibility of the } \\
\text { accounting profession }\end{array}$ & 221 & $51 \%$ & 185 & $43 \%$ & 28 & $6 \%$ & 434 & $100 \%$ \\
\hline 5 & $\begin{array}{l}\text { Loss of true and fair view of } \\
\text { financial statements }\end{array}$ & 194 & $45 \%$ & 214 & $49 \%$ & 26 & $6 \%$ & 434 & $100 \%$ \\
\hline 6 & $\begin{array}{l}\text { Increased confusion for } \\
\text { preparers of financial } \\
\text { statements }\end{array}$ & 182 & $42 \%$ & 231 & $53 \%$ & 21 & $5 \%$ & 434 & $100 \%$ \\
\hline 7 & $\begin{array}{l}\text { Lowering of accounting } \\
\text { standards }\end{array}$ & 169 & $39 \%$ & 239 & $55 \%$ & 26 & $6 \%$ & 434 & $100 \%$ \\
\hline 8 & $\begin{array}{l}\text { Loss of comparability of } \\
\text { financial statements }\end{array}$ & 121 & $28 \%$ & 296 & $68 \%$ & 17 & $4 \%$ & 434 & $100 \%$ \\
\hline 9 & $\begin{array}{l}\text { Application of a differential } \\
\text { accounting system }\end{array}$ & 116 & $27 \%$ & 277 & $64 \%$ & 41 & $9 \%$ & 434 & $100 \%$ \\
\hline
\end{tabular}

From table 3 it seems that, in case the accounting standards applicable to small companies should be lessened, small practitioners would worry about certain issues, namely the nonacceptance of financial statements by financial institutions $(61 \%)$, non-acceptance of financial statements by SARS $(57 \%)$, a reduction in the reliability of financial statements $(52 \%)$ and the loss of credibility of the accounting profession $(51 \%)$. The majority of small practitioners (64\%) indicated that the application of a differential accounting system would not be reason for alarm. The non-acceptance of financial statement by SARS shouldn't be an issue in South Africa, as SARS no longer requires that income tax returns are accompanied by a full set of financial statements. 


\section{CONCLUSION}

The objective of the study was to investigate the opinions of South African small company practitioners, as compilers of small company financial statements, on the applicability of the IFRS for SMEs. The IFRS for SMEs, which is currently applicable in South Africa, remains too comprehensive for the majority of small companies. The IFRS for SMEs does not satisfy the needs of South African users of small company financial statements, and as a result the accounting requirements should be simplified. The results from this study have shown that in practice several accounting standards are never applied by the majority of practitioners. Accounting standards that are regularly applied are the following: IAS 1: Presentation and exposure of financial statements; IAS 7: Cash flow statements; IAS 16: Property, plant and equipment; IAS 2: Inventories; IAS 12: Income tax and IAS 18: Revenue. The burden on small companies to prepare financial statements should be alleviated through the reduction of the disclosure requirements, simplification of the measurement requirements and a decrease in the number of accounting standards applicable to these companies.

On the other hand, the IFRS for small and medium sized entities is a well-considered document and the result of an extensive process. Furthermore, the maintenance of the accounting standard is primarily the responsibility of the IASB and this will also facilitate the updating of the standard. However, the results of this study have shown that the IFRS for SMEs remains too comprehensive for the majority of small companies in South Africa. It is thus recommended that the IFRS for SMEs is simplified even further in order to satisfy the needs of the South African users of small company financial statements. The regulatory framework in South Africa for the drafting of accounting standards is changing with the implementation of the new Companies Act 71 of 2008. A new independent regulatory body, the Financial Reporting Standards Council (FRSC) will be formed in terms of the legislation with the purpose of issuing future accounting standards (South Africa, 2008). The FRSC will replace the Accounting Practices Board (APB) of the South African Institute of Chartered Accountants (SAICA), which has traditionally been responsible for the setting of South African accounting standards. In view of the important contribution of small companies to the South African economy, the financial reporting of these companies is important and the current reporting requirements should be reduced and simplified to ensure that meaningful, relevant and reliable information is contained in financial statements.

This study covers a new area of research, namely the application of the IFRS for SMEs, which might be valuable for different role players, including the FRSC, involved in the accounting for SMEs. As the aim of this study was not to determine a reporting framework for small companies, further research is necessary to determine what the exact simplified reporting accounting requirements for small companies should be.

\section{BIBLIOGRAPHY}

Accounting Standards Board (ASB). 2008. Financial Reporting Standard for Smaller Entities (FRSSE). London: ASB.

Ashby, M.J. 1980. Does Canada need two GAAPs? CA Magazine, June:28-31.

Australian Accounting Standards Board (AASB). 2009. An update on the Differential Reporting Project. Sydney: AASB. [Online] Available from: http://www.charteredaccountants.com.au/ [Accessed: 2009-06-30].

Barcelo, Y. 2007. Standard overload blues. CA Magazine, 140(4):25-30.

Baskerville, R. \& Simpkins, K. 1997. Framework for Differential Reporting. Chartered Accountants Journal, 14-17.

Boymal, D. 2006. Differential reporting - where is it heading? Abacus, 43(1):107-110. 
Burke, J.F. 1997. Report on standards overload. The CPA Journal, 11.

Canadian Institute of Chartered Accountants (CICA). 2001. Exposure draft - Differential reporting. Toronto: CICA.

Canadian Institute of Chartered Accountants (CICA). 2002. Differential reporting, Section 1300 and related amendments to other sections. Toronto: CICA.

Canadian Institute of Chartered Accountants (CICA). 2007. Discussion paper - Financial reporting by private enterprises. Toronto: CICA.

Canadian Institute of Chartered Accountants (CICA). 2009. Exposure draft - Generally Accepted Accounting Principles for private enterprises. Toronto: CICA.

Chigbo, O. 1998. GAAP under fire. CA Magazine, 22-30.

Cleminson, J. \& Rabin, E. 2002. The reporting problems faced by small business entities in South Africa. Paper presented at the Southern African Accounting Association Conference, Port Elizabeth, SA.

Hattingh, C.P. 2002. The final word on differential accounting. Accountancy SA, 23-24.

Heymans, H. 2000. Differential reporting standards. Accountancy SA, 31.

Institute of Chartered Accountants in Australia (ICAA). 2004. Business practice guide Financial statements of non-reporting entities. Melbourne: ICAA.

Institute of Chartered Accountants in Australia (ICAA). 2006. Business practice guide Financial statements of non-reporting entities. Melbourne: ICAA.

Institute of Chartered Accountants of New Zealand (ICANZ). 2007. Framework for differential reporting. Wellington: ICANZ [Online] Available from: http://www.nzica.com/ [Accessed: 2008-06-10].

International Accounting Standards Board (IASB). 2007a. Exposure draft of a proposed IFRS for small and medium-sized entities. London: IASCF-IASB.

International Accounting Standards Board (IASB). 2007b. Basis of conclusions on exposure draft - IFRS for small and medium-sized entities. London: IASCF-IASB.

International Accounting Standards Board (IASB). 2009a. International financial reporting standard for small and medium-sized entities (IFRS for SMES). London: IASCF-IASB. [Online] Available from: http://www.iasb.org/ [Accessed: 2009-07-15].

International Accounting Standards Board (IASB). 2009b. International financial reporting standard for small and medium-sized entities (IFRS for SMEs). Basis for conclusions. London: IASCF-IASB. [Online] Available from: http://www.iasb.org/ [Accessed: 2009-0715].

International Accounting Standards Board (IASB). 2009c. IASB publishes IFRS for SMEs.

Press Release. [Online] Available from: http://www.iasb.org/ [Accessed: 2009-07-15].

Jeffrey, G. 2007. IFRS: reporting standards in transition. CMA Management, 81(6):22-27.

Kent, P. \& Munro, L. 1999. Differential reporting and the effect of loan evaluations: an experimental study. Accounting Forum, 23(4):359-377.

King, H. 1997. Small really is beautiful, and don't you forget it. Accountancy International Edition, 69.

Kruger, R. 2004. Harmonising user needs with reporting requirements of close corporations. Unpublished thesis for a Master of Commerce Degree in Accounting. Bloemfontein: University of the Free State. 
Maingot, M. \& Zeghal, D. 2006. Financial reporting of small business entities in Canada. Journal of Small Business Management, 44(4):513-530.

McAleese, G. 2001. FRSSE: the solution to accounting for small companies? Accountancy Ireland Magazine, 33(1):18.

Murphy, R. \& Page, M. 1998. Small, but imperfectly formed. Accountancy International Edition, 64.

Nieman, G. 2006. Small business management. A South African approach. Pretoria: Van Schaik.

Patel, C. 1991. Differential reporting: for and against. Accountants Journal, 79-81.

Perrin, S. 1997. Firms split over FRSSE. Accountancy Age, 1.

Plewa, F.J. \& Friedlob, G.T. 1989. Are GAAP statements worth it? Management Accounting, 70(7):55.

Santoro, J. 1997. International update. Latest developments in New Zealand. Accountancy and Finance Update, 23-24.

Sealy-Fisher, V. 2009. IASB's IFRS for SMEs. Chartered Accountants Journal of New Zealand, 88(6):30-32.

Shearer, B. \& Sleigh-Johnson, N. 2007. Decision time for private company GAAP? Accountancymagazine.com, 139(1364):78-79.

South Africa. 2008. Companies Act, No. 71 of 2008. Johannesburg: Lex Patria.

South African Institute of Chartered Accountants (SAICA). 2000. Discussion paper 16 Limited purpose financial statements: a discussion draft. Johannesburg: SAICA.

South African Institute of Chartered Accountants (SAICA). 2003. ED 163 - Framework for the preparation and presentation of limited purpose financial statements. Johannesburg: SAICA.

South African Institute of Chartered Accountants (SAICA). 2007a. Circular 69/07 - Statement of Generally Accepted Accounting Practice for small and medium-sized entities (SMEs). Johannesburg: SAICA.

South African Institute of Chartered Accountants (SAICA). 2007b. ED 225 - Financial reporting for small and medium-sized entities - Proposed process. Johannesburg: SAICA.

Stainbank, L.J. \& Wells, M.J.C. 2007. Differential corporate reporting: registered accountants' and auditors' views in South Africa. South African Journal of Accounting Research, 21(1):31-55.

Van Wyk, H.A. \& Rossouw, J. 2008. IFRS for SMEs in South Africa: a giant leap for accounting, but too big for smaller entities. Paper presented at the SAAA Biennial Conference, Emperors Palace, Johannesburg.

Walton, P. 1998. Differential reporting. Accountancy and Finance Update, June:2-3. 